\title{
STATUS PEWARISAN TRANSEKSUAL DALAM PERSPEKTIF HUKUM WARIS ADAT
}

MINANGKABAU

STATUS OF TRANSSEXUAL INHERITANCE IN THE
PERSPECTIVE OF MINANGKABAU CUSTOMARY LAW

JURNAL

POROS HUKUM

PADJADJARAN

P-ISSN: 2715-7202

E-ISSN: 2715-9418

Artikel diterbitkan:

29 Mei 2020

DOI:

https://doi.org/10.23920/jphp .v1i2.248

Halaman Publikasi:

http://jurnal.fh.unpad.ac.id/i ndex.php/JPHP/issue/archive

Diterbitkan oleh:

Fakultas Hukum

Universitas Padjadjaran

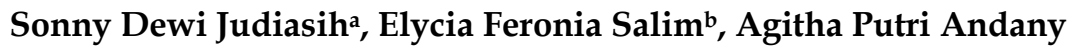 \\ Hidayat ${ }^{c}$, Cynthia Kurniawan ${ }^{d}$, Rifny Meirizka ${ }^{e}$, Firsty Anandini ${ }^{f}$
}

\begin{abstract}
ABSTRAK
Seiring perkembangan zaman, dewasa ini terdapat orang yang berkeinginan mengubah jenis kelaminnya yang disebut sebagai transeksual. Faktor yang menyebabkan seseorang menjadi transeksual selain dari faktor hormonal dapat juga terjadi karena pengaruh faktor lingkungan. Dalam hal ini akan menimbulkan masalah dalam segala aspek hukum dan bidang kehidupan salah satunya terkait dengan pewarisan bagi transeksual. Di Indonesia, eksistensi hukum adat terutama dalam hal waris masih diakui. Masyarakat adat khususnya adat Minangkabau yang menjunjung tinggi nilai-nilai dan norma agama Islam tentunya menolak keberadaan transeksual di lingkungan mereka dan dengan ditolaknya keberadaan transeksual di Adat Minangkabau, transeksual tidak berhak dalam pewarisan dalam waris adat khususnya di Minangkabau. Tujuan dari penulisan ini adalah untuk mengetahui, menjelaskan dan menganalisis tentang pewarisan transeksual dalam Hukum Waris Adat Minangkabau.
\end{abstract}

Kata kunci: agama; hukum adat; hukum waris; transeksual.

\begin{abstract}
Along with the times, there are people who wants to change their sex, which is called transsexual. Factor that cause a person to become transsexual aside from hormonal factors can also occur due to the influence of environmental factors. On the other hand returning to norms and religion is considered to violate the norms and values of custom and religion, in this case, it will cause problems in all aspects of law and life, one of which is related to inheritance for transsexual. In Indonesia, the existence of Adat Law esspecialy in heir matter still recognized. Indigenous peoples especially Adat Minangkabau, who uphold Islamic religious values and norms naturally reject the existence of transsexual in their environment. There fore, transsexual are not entitled to
\end{abstract}

a Fakultas Hukum Universitas Padjadjaran, Jalan Raya Bandung-Sumedang KM.21 Jatinangor Kab. Sumedang, email: sonny@unpad.ac.id.

b Magister Kenotariatan Fakultas Hukum Universitas Padjadjaran, Jl. Hayam Wuruk No.2, Bandung, email: intan_salim@yahoo.com.

c Magister Kenotariatan Fakultas Hukum Universitas Padjadjaran, Jl. Hayam Wuruk No.2, Bandung: agithaputri2103@gmail.com.

d Magister Kenotariatan Fakultas Hukum Universitas Padjadjaran, Jl. Hayam Wuruk No.2, Bandung, email: cynthiaceka23@gmail.com.

e Magister Kenotariatan Fakultas Hukum Universitas Padjadjaran, Jl. Hayam Wuruk No.2, Bandung, email: rifnymei@gmail.com.

f Magister Kenotariatan Fakultas Hukum Universitas Padjadjaran, Jl. Hayam Wuruk No.2, Bandung, email: firstyanandini@gmail.com. 
inhertitance in Adat Minangkau in inheritance. The purpose in this paper is to find out, explain, and analyze abput transsexual inhertitance in Minangkabau Adat Law.

Keywords: adat law: inheritance adat law; religion; transsexual.

\section{PENDAHULUAN}

Hukum seperti halnya dengan hukum dimanapun di dunia mengikuti jiwa dari bangsa masyarakatnya, karena hukum itu senantiasa tumbuh dari sesuatu kebutuhan hidup yang nyata, cara hidup dan pandangan hidup dari bangsa atau masyarakatnya, yang keseluruhannya merupakan kebudayaan masyarakat tempat hukum adat itu berlaku. ${ }^{1}$ Manusia merupakan makhluk sosial dimana dalam memenuhi kebutuhan dasarnya manusia hampir selalu berhubungan dengan satu sama lain. Dalam pergaulan sesamanya, terdapat patokan-patokan yang merupakan struktur kaidah untuk tetap mempertahankan hidup secara damai. ${ }^{2}$ Struktur kaidah tersebut menjelma dalam pola tingkah laku masyarakat.

Dalam proses perkembangannya, suatu bangsa memiliki adat kebiasaan yang berbeda antara satu dengan yang lainnya. Pola tingkah laku masyarakat tentunya berbeda-beda di setiap negara atau daerahnya. Indonesia merupakan negara yang berkepribadian Pancasila yang berarti bahwa secara tidak langsung hukum Adatnya pun berkepribadian Pancasila pula. ${ }^{3}$ Perbedaan adat tersebut merupakan unsur yang terpenting dan dapat memberikan ciri serta identitas diri bangsa yang bersangkutan. ${ }^{4}$ Penyelesaian sengketa dengan menerapkan hukum adat dirasa lebih menunjukkan keadilan dan lebih mempunyai kekuatan nilai jika dibandingkan dengan hukum nasional yang cenderung bersifat diskriminan. ${ }^{5}$

Sebagian sangat besar hukum adat ini masih tidak tertulis serta berupa kaidahkaidah kehidupan sehari-hari yang penting di dalam pergaulan masyarakat dan yang dikenal oleh masyarakat yang bersangkutan. ${ }^{6}$ Hukum adat di Indonesia juga seringkali Digunakan dalam penyelesaian suatu sengketa yang timbul, salah satunya ialah mengenai waris. Hukum waris di Indonesia masih pluralistik, salah satunya ialah hukum waris adat. Dalam system hukum waris adat, dikenal 3 (tiga) sistem hukum

\footnotetext{
1 Soerojo Wignjodipoero, (1983). Pengantar dan Asas-Asas Hukum Adat, Jakarta: PT. Toko Gunung Agung, hlm. 60.

2 Albar S. Subari, dkk, (2010). Pokok-Pokok Hukum Adat, Palembang: Penerbit Universitas Sriwijaya, hlm. 8.

3 Soerojo Wignjodipoero, Pengantar dan Asas-Asas Hukum Adat, Loc.Cit.

4 Sri Warjiyati, (2018). Eksistensi Hukum Adat Dalam Penyelesaian Konflik pada Daerah Otonom, AHKAM, Jurnal Hukum Islam, Volume 6 Nomor 2, hlm. 390.

5 Ibid, hlm. 391.

6 Soerojo Wignjodipoero, Pengantar dan Asas-Asas Hukum Adat, Op. Cit, hlm. 61.
} 
pembagian waris, yakni sistem hukum waris adat patrilineal, sistem hukum waris adat matrilineal, dan sistem hukum waris adat parental. Sistem hukum waris adat patrilineal ialah berdasarkan garis keturunan laki-laki atau ayah, sistem hukum waris adat matrilineal berdasarkan garis keturunan ibu atau perempuan, dan sistem hukum waris adat parental berdasarkan garis keturunan laki-laki dan perempuan atau ayah dan ibu.

Sistem hukum waris adat matrilineal sebagian besar digunakan oleh masyarakat Adat Minangkabau. Matrilineal berasal dari kata-kata Matriakat artinya "ibu yang berkuasa". Dewasa ini, pengertian Ibu yang berkuasa sudah tidak dipakai lagi karena sistem ibu yang berkuasa sudah tidak ada, yang ada hanyalah kelompok masyarakat yang menganut prinsip Matrilineal, yaitu dalam menarik garis keturunannya seseorang menghubungkan diri dari pada Ibu. ${ }^{7}$ Masyarakat Minangkabau tersebut berbentuk suatu organisasi yang berada dlam satu istilah bernama paruik, ${ }^{8}$ dimana keseluruhan keluarga berkumpul dalam suatu lingkungan tempat tinggal yakni yang disebut rumah gadang. Kaum ibu pada masyarakat Minangkabau sangat dihormati, ibu disebut "Bundo Kanduang" adalah sebagai amban paruik (bendaharawan) yang tugasnya adalah memegang peran sentral dalam pendidikan, pengamanan, kekayaan dan kesejahteraan keluarga.

Hukum adat tidak statis, melainkan dinamis. Soepomo mengatakan bahwa hukum adat terus menerus dalam keadaan tumbuh dan berkembang seperti hidup itu sendiri. Situasi yang timbul dalam keadaan dan perkembangan masyarakat pada saat ini mulai keluar dari nilai-nilai dan norma adat serta agama. Keadaan yang didasari pada kata-kata "hak asasi manusia" seringkali menjadikan hal tersebut sebuah pembenaran yang padahal telah melanggar nilai dan norma. Salah satu contohnya ialah mengenai Transgender dan Transeksual. Dalam kehidupan masyarakat, kita mengenal istilah transgender ataupun transeksual yang dianggap sebagai identitas gender diluar laki-laki dan perempuan secara natural. ${ }^{9}$ Transgender adalah seseorang yang mengenakan atribut-atribut gender berlainan dengan konsepsi gender yang

\footnotetext{
7 Amir. M. S., (2001). Adat Minangkabau Pola dan Tujuan Hidup Orang Minang, Jakarta: PT. Mutiara Sumber Widya, hlm 22

8 Yelia Nathassa Winstar, (2007). Pelaksanaan Dua Sistem Kewarisan Pada Masyarakat Adat Minangkabau, Jurnal Hukum dan Pembangunan, Volume 37 Nomor 2, hlm. 22.

9 Anindita Ayu Pradipta Yudah, (2013). Representasi Transgender dan Transeksual dalam Pemberitaan di Media Massa: Sebuah Tinjauan Analisis Wacana Kritis, Jurnal Kriminologi Indonesia, Volume 9 Nomor 1, hlm. 37.
} 
dikonstruksikan secara sosial oleh masyarakat, sedangkan transeksual adalah seseorang yang merasa dirinya mempunyai jenis kelamin yang salah. ${ }^{10}$

Diskriminasi terhadap transgender dan transeksual berasal dari stigmatisasi terhadap mereka yang memilih 'berbeda' dengan masyarakat di lingkungan sekitar. Stigmatisasi ini berkembang begitu kental di dalam konteks masyarakat Indonesia. Selain dilatari oleh konstruksi patriarki yang begitu kental di mana laki-laki dikonstruksikan adalah makhluk yang jantan, stigma terhadap transgender dan transeksual juga dikaitkan dengan homophobia yang terkadang bersumber pada keyakinan agama. ${ }^{11}$

Di Indonesia, keberadaan transgender dan transeksual tidak diakui, tentu saja karena dianggap melanggar nilai-nilai serta norma yang ada. Nilai-nilai dan norma yang dilanggar tersebut termasuk ke dalam nilai-nilai dan norma agama serta adat masyarakat setempat. Seperti yang kita ketahui, dalam hukum waris adat di Indonesia, hanya terdapat dua sistem keturunan yakni laki-laki dan perempuan. Keberadaan transgender dan transeksual ini tidak serta merta menjadikan identitas baru mereka sebagai transgender maupun transeksual mengikuti sistem hukum waris adat yang ada. Keberadaan mereka yang dianggap melanggar nilai dan norma adat serta agama juga bahwa bagaimanakah status identidas mereka dalam penerimaan waris dan apakah mereka masih bisa menerima waris sesuai dengan aturan sistem hukum waris adat yang ada. Berdasarkan pemaparan tersebut, maka tulisan ini akan mengkaji mengenai:

1. Bagaimanakah status hukum transeksual dalam masyarakat Matrilineal di Minangkabu?

2. Bagaimanakah kedudukan hukum transeksual dalam pewarisan pada masyarakat Matrilineal?

\section{PEMBAHASAN}

\section{Status Hukum Transeksual dalam Masyarakat Matrilineal di Minangkabau}

Fenomena transgender dan transeksual merupakan hal yang tidak asing lagi di Indonesia. Hal ini terjadi karena perkembangan teknologi yang semakin berkembang dan adanya jaringan internet yang dapat mempermudah manusia untuk mengakses sehingga mengetahui perkembangan zaman saat ini. Globalisasi ini salah satunya

\footnotetext{
${ }^{10} \mathrm{Ibid}, \mathrm{hlm} .38$
}

${ }^{11}$ Ibid, hlm. 38-39. 
menjadi jalan untuk adanya fenomena baru yaitu mengenai Lesbian Gay Biseksiual dan Transgender/Transeksual (LGBT). Transgender dan Transeksual, kedua hal tersebut mempunyai makna yang berbeda, transgender bukan merupakan suatu identifikasi yang sama dengan transeksual. ${ }^{12}$ Transgender merupakan orang yang bernampilan tidak sesuai dengan gender yang telah diterimanya sejak lahir.13 Sedangkan, transeksual adalah individu secara pembedahan melakukan perubahan pada alat kelamin dan tubuhnya. ${ }^{14}$

Indonesia merupakan negara yang berpegang teguh pada nilai-nilai dan ajaran agama, sehingga tentunya perilaku menyimpang seksual seperti Transgender dan Transeksual tidak dapat diterima oleh masyarakat. Di sisi lain, Indonesia merupakan negara yang mengakui Hak Asasi Manusia (HAM), dimana kaum Lesbian, Gay, Biseksual, dan Transgender (LGBT) merasa mengalami diskriminasi dan pelanggaran hak asasi manusia karena orientasi seksual mereka yang menyimpang. ${ }^{15} \mathrm{Hal}$ ini merupakan suatu permasalahan yang timbul di dalam kehidupan bermasyarakat di Indonesia.

Perilaku transeksual di Indonesia menjadi hal yang tabu, masyarakat berpegang teguh dengan nilai-nilai agama, moral dan kesusilaan. Perilaku tersebut muncul atas dasar orientasi seksual yang menyimpang orientasi seksual adalah kecenderungan seseorang untuk mengarahkan rasa ketertarikan, romantisme, emosional, dan seksualnya kepada pria, wanita maupun kombinasi keduanya. ${ }^{16}$ Kecenderungan seseorang berperilaku transeksual akibat keresahan dirinya atas jenis kelamin yang diterimanya saat dia lahir.

Latar belakang Organisasi LGBT dan LGBT di Indonesia, dengan Implementasi hak asasi manusia tanpa pertimbangan orientasi seksual seseorang dan identitas gender bukanlah masalah. Namun, Organisasi Non-Pemerintah (LSM), manusia hak dan aktivis LGBT secara konsisten memperjuangkan pengakuan dan hak LGBT, baik di

\footnotetext{
12 Judith Halberstam, (2005). In a Queer Time and Place: Transgender Bodies Subcutural Lines, NYU: Press, hlm. 46.

${ }^{13}$ Garland, 2009, Hate Crime: Impact, Causes, and Respons, Londong: SAGE Publication, hlm. 23.

${ }^{14}$ Ibid.

${ }^{15}$ Roby Yansyah dan Rahayu, (2018). Globalisasi Lesbian, Gay, Biseksual, dan Trangender (LGBT): Perspektif HAM dan Agama dalam lingkup Hukum di Indonesia, Jurnal Law Reform, Volume 14 Nomor 1, hlm 132.

${ }^{16}$ Crews Douglas dan Crawford Marcus, (2015). Exploring the Role of Being Out on a queer Person's Self Compassion, Journal of GayELesbian Social Services, Vol. 27 No. 2, hlm. 172-186.
} 
tingkatan nasional dan internasional. Upaya tak kenal lelah yang mereka miliki, mengakibatkan perkembangan baru pada masalah LGBT di Indonesia. ${ }^{17}$

Dalam hukum nasional di Indonesia, mengenai transeksual mempunyai kedudukan yang sama berdasarkan hak asasi manusia dalam Undang-Undang Dasar 1945 Pasal 28 J bahwa setiap orang wajib menghormati hak asasi manusia orang lain dalam tertib kehidupan bermasyarakat, berbangsa, dan bernegara, lalu dalam menjalankan hak dan kebebasannya, setiap orang wajib tunduk kepada pembatasan yang ditetapkan dengan undang-undang dengan maksud semata-mata untuk menjamin pengakuan serta penghormatan atas hak dan kebebasan orang lain dan untuk memenuhi tuntutan yang adil sesuai dengan pertimbangan moral, nilai-nilai agama, keamanan, dan ketertiban umum dalam suatu masyarakat demokratis.

Pergantian jenis kelamin melalui administrasi diperbolehkan berdasarkan Undang-Undang Nomor 23 Tahun 2006 tentang Administrasi Kependudukan Pasal 2 bahwa tiap penduduk berhak memperoleh dokumen kependudukan meliputi data pribadi termasuk jenis kelamin sesuai dengan keadaan tiap penduduk.bahwa pihak yang ingin melakukan perubahan jenis kelaminnya harus melakukan permohonan melalui Pengadian Negeri untuk menerima penetapan perubahan jenis kelamin.

Selain dalam Undang-Undang Nomor 23 Tahun 2006, dalam hukum positif di Indonesia diatur dalam Undang-Undang Nomor 39 Tahun 1999 Tentang Hak Asasi Manusia Pasal 3 ayat 2 bahwa setiap orang berhak atas pengakuan, jaminan, perlindungan, dan perlakuan hukum yang adil serta mendapatkan kepastian hukum dan perlakuan yang sama dalam hukum. Sehingga, pihak transeksual berdasarkan hak asasi manusianya dilindungi keberadaannya dan mendapakan kedudukan yang sama dalam hukum. Oleh karena itu, secara tersirat perubahan kelamin atau transeksual yang dilakukan oleh seseorang sah menurut hukum Indonesia.

Fenomena mengenai LGBT ini, khususnya transeksual, tidak hanya menjadi suatu permasalahan dalam tata kehidupan suatu negara khususnya Indonesia secara garis besar. Munculnya transeksual ini juga harus dipertanyakan bagaimana status dan kedudukannya di kehidupan bermasyarakat, khususnya masyarakat adat. Dari banyaknya masyarakat adat di Indonesia, masyarakat Adat Minangkabau merupakan

\footnotetext{
${ }^{17}$ Yulianti Muthmainnah, (2016). LGBT Human Rights in Indonesian Policies, Indonesian Feminist Journal, Volume 4 No 1 , hlm 16.
} 
salah satu kelompok masyarakat yanga adatnya berpegang teguh pada ajaran Agama Islam.

Dalam menjalani kehidupan sehari-hari di Minangkabau, masyarakat adat Minangkabau mengacu dan berpanutan pada pepatah-pepatah yang tumbuh dan hidup dalam kehidupan bermasyarakatnya. Salah satu pepatah adat yang menjadi tonggak utama dalam kehidupan bermasyarakat di Minangkabau adalah "Adat Basandi Syarak, Syarak Basandi Kitabullah"18 yang berarti bahwa adat bersendi pada syariat atau agama, syariat atau agama bersendi pada Kitab Allah. Kitab Allah menurut masyarakat Minangkabau adalah Al-Qur'an, karena masyarakat Minangkabau memeluk agama Islam. Menurut Sutan Syahrul, Ketua Kerapatan Adat Nagari 8 Suku Minangkabau, masyarakat Minangkabau sangat kental dengan Agama Islam, segala sesuatunya harus berdasar Al-Qur'an. ${ }^{19}$ Maka dari itu, segala sesuatu tingkah laku dan perbuatan masyarakat di Minangkabau harus sejalan dengan hukum Islam. Mengenai transeksual tentu saja hal tersebut tidak dibenarkan menurut ajaran agama, terutama ajaran Agama Islam. Karena menurut ajaran Agama Islam hal tersebut (transeksual) tidak sesuai dengan kodrat dan hakikat manusia. Bahwa hakikat manusia dalam Al-Qur'an dikatakan:

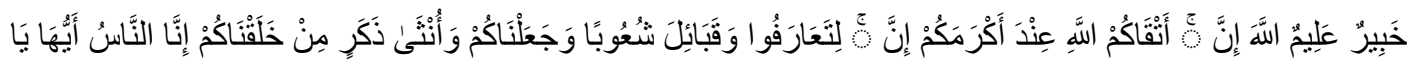

artinya "Hai manusia, sesungguhnya Kami menciptakan kamu dari seorang laki-laki dan seorang perempuan dan menjadikan kamu berbangsa-bangsa dan bersuku-suku supaya kamu saling kenal-mengenal. Sesungguhnya orang yang paling mulia diantara kamu disisi Allah ialah orang yang paling takwa diantara kamu. Sesungguhnya Allah Maha Mengetahui lagi Maha Mengenal". Bahwa diciptakan manusia itu laki-laki dan perempuan, bukan laki-laki dan laki-laki ataupun perempuan dan perempuan, maka diciptakanlah adam dan hawa sebagai pasangan. Dijadikan kamu itu bersuku-suku dan berbangsa-bangsa guna saling mengenal satu sama lain.

Dalam riwayatnya terdapat percakapan dua sahabat diantara Umar bin Khattab RA dengan Ubay bin Ka'ab. Ubay mengatakan kepada Umar bahwa taqwa itu berarti berhati-hati dalam melakukan segala sesuatu dalam kehidupan ini, baik dari segi perilaku maupun tindakan. Dalam hukum agama Islam, jenis kelamin yang dimiliki

\footnotetext{
${ }^{18}$ Sonny Dewi Judiasih, dkk, (2019). Sustainable Development Goals and Elimination of Children's Marriage Practice in Indonesia, Jurnal Notariil, Volume 4 Nomor 1, hlm. 61.

${ }^{19}$ Wawancara Sutan Syahrul Nurmay, Ketua Kerapatan Adat Nagari 8 Suku Nagari Padang, Minangkabau, tanggal 10 Desember 2018.
} 
oleh seseorang adalah merupakan kodrat (ketentuan) Allah, maka dalam hukum Islam tidak diperbolehkan melakukan operasi perubahan kelamin. Adapun dalil-dalil yang mengharamkan operasi ganti kelamin antara lain Al-Qur'an surat Al-Hujarat ayat 13 dan Al-Qur'an surat An-nisa' ayat 119

“Dan aku benar-benar akan menyesatkan mereka, dan akan membangkitkan angan-angan kosong pada mereka dan menyuruh mereka (memotong telinga-telinga binatang ternak), lalu mereka benar-benar memotongnya, dan akan aku suruh mereka (mengubah ciptaan Allah), lalu benar-benar mereka merubahnya". Barangsiapa yang menjadikan syaitan menjadi pelindung selain Allah, maka sesungguhnya ia menderita kerugian yang nyata."

Di dalam kitab shafwatul bayan disebutkan beberapa perbuatan manusia yang diharamkan karena termasuk "mengubah ciptaan tuhan", seperti mengebiri manusia, homo seksual, lesbian, menyambung rambut dengan sopan, artinya orang pria berpakaian dan bertingkah laku seperti wanita atau sebaliknya. Hadis nabi riwayat Bukhari dan enam ahli hadits lainnya dari Ibnu Mas'ud dan nilai hadisnya sahih, bahwa apa yang telah diciptakan oleh Allah tidak boleh dirubah. Demikian pula seorang pria atau wanita yang lahir normal jenis kelaminnya tetapi karena lingkungan, menderita kelainan semacam kecenderungan seksnya yang menjadikan "banci" dengan berpakaian dan bertingkah laku yang berlawanan dengan jenis kelaminnya. Sebab pada hakikatnya organ/jenis kelaminnya normal tetapi psikisnya tidak normal. Dan Islam pun melarang seseorang berpakaian dan bertingkah laku berlawanan dengan jenis kelaminnya. Hal ini dilarang oleh agama berdasarkan hadits nabi, Allah mengutuk wanita-wanita yang menyerupai pria-pria dan pria-pria yang menyerupai wanitawanita.

Ketidakbolehan atau haram hukumnya melakukan transeksual (operasi kelamin) juga ditegaskan dalam fatwa Majelis Ulama Indonesia tanggal 1 Juni 1980, keputusan nomor 1: "Merubah jenis kelamin laki-laki menjadi perempuan atau sebaliknya hukum haram, karena bertentangan dengan al-Quran surat an-Nisa' ayat 119 dan bertentangan pula dengan jiwa syara'. ${ }^{20}$

Melihat dari ajaran-ajaran Agama Islam tersebut, dapat disimpulkan bahwa apabila laki-laki dan perempuan diciptakan sesuai kodrat dan kehendak-Nya. Manusia

\footnotetext{
${ }^{20}$ Majelis Ulama Indonesia, (2010). Himpunan Fatwa Majelis Ulama Indonesia, Edisi Ketiga, (Jakarta, 2010), hlm. 561.
} 
tidak boleh merubah apa yang telah difitrahkan padanya. Ajaran inipun menjadi pedoman dalam kehidupan masyarakat adat di Minangkabau.

Keberadaan transeksual di Minangkabau tidak akan diterima oleh masyarakat atau Nagari. Nagari disini maksudnya adalah sebuah republik kecil (julukan yang diberikan oleh Belanda) yang mempunyai pemerintahan sendiri secara otonom dan berbasis pada masyarakat (self-governing community). ${ }^{21}$ Tatanan hidup bernagari, segala permasalahan yang ada di suatu nagari harus diselesaikan secara bajanjang naiak dan batanggo turun, artinya semua permasalahan harus diselesaikan mulai dari bawah yaitu mulai dari mamak kemudian kepada kepala kaum. ${ }^{22}$ Jika permasalahan tersebut tidak selesai di kepala kaum, maka akan diteruskan kepada penghulu suku. Apabila tidak selesai permasalahan tersebut maka barulah sampai kepada Kerapatan Adat Nagari. ${ }^{23}$

Di Minangkabau ada pepatah yang menyatakan bahwa “Dibuang Jauah di Gantuang Tinggi" yang berarti dikeluarkan dari kaum, baik dari silsilah kaum adat maupun dari dalam Nagari atau lingkungan adat. Seseorang yang melanggar normanorma dan melampaui batas kesopanan di lingkungan masyarakat adat, akan dikucilkan bahkan diusir dari kehidupan bermasyarakat adat Minangkabau. Seseorang yang seperti itu tidak berhak lagi dalam seluruh hal baik kegiatan, acara adat, hingga termasuk penerimaan waris adat Minangkabau. Seseorang yang dianggap melakukan suatu hal yang membuat malu kaum atau keluarga akan dikucilkan dan diusir.

\section{Kedudukan hukum Transeksual dalam Pewarisan pada masyarakat Matrilineal}

Garis keturunan ibu di Minangkabau erat kaitannya dengan sistem kewarisan sako dan pusako. Seandainya garis keturunan mengalami perubahan maka akan terjadi suatu perubahan dari sendi-sendi adat Minangkabau sendiri. ${ }^{24}$ Oleh karena itu, bagi masyarakat Minangkabau garis keturunan bukan hanya sekedar menentukan garis keturunan anak-anaknya, melainkan erat sekali hubungannya dengan adatnya. ${ }^{25}$ Pembagian warisan berdasarkan garis keturunan perempuan di Minangkabau tidak

\footnotetext{
${ }^{21}$ Afdhal Prima, (2014). "Sistem Pemerintahan Nagari (Studi Pada Nagari Padang Magek Kabupaten tanah Datar)", Vol 1 No 2, hlm. 2.

${ }^{22}$ Sonny Dewi Judiasih, dkk, (2019). Sustainable Development Goals: Upaya Penghapusan Perkawinan Bawah Umur di Indonesia, Bandung: Cakra, hlm. 86.

${ }^{23}$ Velly Fahazra Arza, dkk, (2017). Kewenangan Kerapatan Adat Nagari (KAN) Dalam Pnyelesaian Sengketa Tanah Ulayat di Nagari Koto Baru Kabupaten Solok Berdasarkan Perda Sumatera Barat No.6 Tahun 2008, Vol 6 No 2, hlm. 2.

${ }^{24}$ Ulfa Chaerani Nuriz, dkk, (2017). Penerapan Hukum Adat Minangkabau Dalam Pembagian Warisan Atas Tanah, Diponegoro Law Journal, Volume 6 Nomor 1, hlm. 3. 
serta merta tanpa alasan. Pada dasarnya sistem matrilineal bukanlah untuk mengangkat peranan perempuan, tetapi dikukuhkan untuk menjaga, melindungi harta pusaka suatu kaum dari kepunahan, baik rumah gadang, tanah pusaka dan sawah ladang. 26

Dasar pewarisan dalam Adat matrilineal Minangkabau dalam hal ahli waris dinyatakan dalam pepatah Adat yang mengatakan:

"Birik-birik turun ke semah

tibah disemah berilah makan

Harta ninik turun ke mamak

dari mamak turun ke kemenakan"

Berdasarkan pepatah Adat, yang merupakan hukum Adat tersebut, menunjukan bahwa harta ninik turun ke mamak dan mamak turun ke kemenakan, berarti harta warisan yang merupakan harta pusaka turun golongan perempuan (ninik, mamak dan kemenakan), dan pengertian ninik, mamak, dan kemenakan itu tidak boleh dipahami orang-perorang, tetapi harus dipahami sebagai kelompok atau generasi. Sedangkan harta warisan yang bukan harta pusaka atau harta suarang tidaklah demikian. Karena harta suarang adalah harta bersama antara suami istri, di mana harta tersebut didapat oleh suami dan istri selama perkawinan, sehingga apabila salah satu meninggal dunia baik suami maupun istri, maka suami atau istri akan mendapat $1 / 2$ (setengah) dari harta suarang tersebut yang berarti masing-masing kembali kepada suami atau istri. Pada awalnya harta peninggalan istri akan tetap menjadi miliknya dan diwariskan sepenuhnya kepada generasi selanjutnya yang perempuan sedangkan untuk suami, harta warisannya akan kembali pada kerabatnya dan tidak diwariskan kepada anaknya karena menganut sistem kekerabatan Matrilineal. Seiring perkembangan dewasa ini, seorang suami dapat menghibahkan harta-harta pencaharianya kepada isterinya dengan tiada keharusan disetujui lebih dahulu oleh kerabat atau keponakan-keponakan, hal ini sesuai dengan Putusan Mahkamah Agung No. 290 K/Sip/1963, ada juga yurisprudensi yang menyatakan bahwa harta pencaharian suami dan istri dalam adat Minangkabau dapat diturunkan kepada anak, akan tetapi harta pusaka tetap menjadi kaum masing-masing pihak, hal ini tercantum dalam Putusan Mahkamah Agung No. 39 K/Sip/1968.

${ }^{26}$ Hamka, (1968). Adat Minangkabau dan Harta Pusakanya, Padang: Center For Minangkabau Studies Press, hlm. 46. 
Dalam pewarisan adat di Minangkabau, seringkali terjadi perselisihan dan perkara yang timbul. Hal ini membuktikan bahwa perlu adanya upaya yang terus menerus, terutama diharapkan ninik mamak pemangku adat, Kerapatan Adat Nagari (KAN), maupun Pengadilan Negeri, agar selalu dapat mencari jalan musyawarah untuk mufakat dalam permasalahan waris mewaris yang terjadi. ${ }^{27}$

Globalisasi LGBT terus meningkat, sehingga diperkirakan di tahun-tahun mendatang, akan ada perkembangan isu utama hak-hak LGBT dalam sekala Global seperti: Pemberantasan penganiayaan berdasarkan orientasi seksual, perlindungan hukum kaum LGBT dari kebencian dan propaganda kebencian, serta hak-hak istimewa yang sama. ${ }^{28}$ Selain itu, dalam Universal Declaration of Human Rights Pasal 2 dinyatakan bahwa:

"everyone is entitled to all the rights and freedoms set forth in this Declaration, without distinction of any kind, such as race, colour, sex, language, religion, political or othe opinion, national or social origin, property, birth or other status...."

Saat ini semakin banyak secara terbuka mengekspresikan orientasi seksual mereka dan menuntut hak-hak mereka. ${ }^{29} \mathrm{Hal}$ ini menimbulkan anggapan bahwa, keputusankeputusan tersebut harus menjadi hak prerogative individu dan laying mendapatkan perlindungan hukum. ${ }^{30}$ Karena hal tersebut, penerimaan hak-hak LGBT di seluruh dunia sedang tumbuh, dan pemerintah negara-negara tertentu mulai membuat undangundang yang mendukung atau hak-hak LGBT dan antri diskriminasi. ${ }^{31}$ Maka dari itu sehubungan dengan sistem pewarisan adat, patut dipertanyakan bahwa bagaimanakah status transeksual dalam sistem pewarisan adat di Minangkabau.

Pepatah dalam adat Minangkabau menyatakan, "bajalan salangkah dipikiri, babaliak salangkah suruik" artinya ada sesuatu hal yang dipikirkan ke belakang atau dievaluasi. ${ }^{32}$ Dalam adat istiadat Minangkabau pepatah seperti itulah yang membuat masyarakat Minangkabau sangat mewaspadai segala kemungkinan-kemungkinan yang terjadi. ${ }^{33}$ Setiap orang harus memikirkan setiap langkah yang diambil dan harus berhatihati.

\footnotetext{
27 Ulfa Chaerani Nuriz, dkk, Penerapan Hukum Adat Minangkabau......., Op.Cit, hlm. 7.

${ }^{28}$ Roby Yansyah dan Rahayu, Globalisasi Lesbian, Gay, Biseksual, ......... Op.Cit, hlm. 136.

29 Ibid.

30 Tia Powell, (2016). Transgender Rights as Human Rights, AMA Journal of Ethics, Volume 18 Nomor 11, hlm. 1129.

${ }^{31}$ Chatterjee Subhrajit, (2014). Problems Faced by LGBT People in Mainstream Society: Some Recommendation, International Journal of Interdisciplinary and Multidisciplinary Studies, Volume 1 Nomor 5, hlm. 317.

32 Wawancara Junaidi, Tokoh Adat: Datuak dalam Suku di Minangkabau, tanggal 18 September 2019.

33 Ibid.
} 
Kebudayaan Adat Minangkabau juga tersirat dari sebuah pepatah yang berbunyi: “Gunuang marapi masih tagak kokoh manjulang, adaik masih tagak kuaik, indak lapuak dek hujan, indak lakang dek paneh". Melihat fenomena yang terjadi saat ini, khususnya mengenai keberadaan transeksual, bisa dikatakan bahwa adat Minangkabau memang tidak akan lapuk karena hujan dan tidak akan lekang oleh panas, akan tetapi perlahan akan terkikis oleh pengaruh budaya asing. Keberadaan transeksual yang pada dulunya masih sangat tabu khususnya di Indonesia, karena adanya pengakuan LGBT di negara-negara lain di dunia, seiring berjalannya waktu keberadaan transeksual mulai muncul di Indonesia. Hal ini jelas sangat bertentangan dengan norma adat dan agama. Sebagaimana yang diketahui bahwa dalam Agama Islam yang menjadi sandaran dan pedoman hidup Masyarakat Adat Minangkabau, bahwa Allah telah menciptakan makhluk-Nya berpasang-pasangan. Masing-masing ciptaan-Nya itu membawa tugasnya sendiri-sendiri, mereka tidak boleh keluar dari ketentuan Allah. Semua aktivitasnya harus sesuai dengan fitrah yang telah dianugerahkan Allah kepadanya. Selain itu dalam ajaran Agama Islam juga terdapat Hadis Nabi riwayat Bukhari dan enam ahli hadits lainnya dari Ibnu Mas'ud dan nilai hadistnya sahih, bahwa apa yang telah diciptakan oleh Allah tidak boleh dirubah.

Mengenai hak waris di dalam Adat Minangkabau, status pewarisan bagi Transeksual ialah bahwa ia tidak lagi dapat menjadi ahli waris dalam pewarisan. Ada pepatah "Alam Takambang Jadi Guru”, bahwa segala sesuatu yang kita lakukan atau diperbuat harus dipelajari terlebih dahulu dengan baik. Melihat pada pepatah “Dibuang Jauah di Gantuang Tinggi" yang berarti dikeluarkan dari kaum. Bahwa baik di nagari maupun di keluarga atau kaum, apalagi dalam silsilah Ranji, nama yang berbuat tidak tercantum lagi, sudah keluar dari anggota Kaum Adat. ${ }^{34}$ Ranji disini maksudnya adalah hubungan atau kaitan antara keluarga sekaum berdasarkan garis keturunan ibu secara Matrilineal. Istilahnya "mencemo" atau merusak kaum. ${ }^{35}$ Haknya atas segala waris akan hilang dengan sendirinya dan bahwa ia tidak lagi pantas menerima waris tersebut. Seperti yang telah dikatakan oleh Hamka, bahwa pada dasarnya sistem matrilineal bukanlah untuk mengangkat peranan perempuan, tetapi dikukuhkan untuk menjaga, melindungi harta pusaka suatu kaum dari kepunahan, baik rumah gadang, tanah pusaka dan sawah ladang. Pewarisan tidak serta merta hanya penerusan suatu harta

${ }^{34}$ Wawancara Marayulius, Tokoh Adat Minangkabau dalam Kerapatan Adat Nagari, tanggal 20 September 2019. 
kekayaan tetapi ada tujuan tertentu dibaliknya, karena di Minangkabau harta pusaka tidak hanya berupa harta peninggalan yang berasal dari orang tua atau yang dihasilkan oleh orang tua. Akan tetapi harta pusaka di Minangkabau juga terdiri dari harta pusaka tinggi yang mana harta tersebut diturunkan secara turun temurun untuk dijaga dan tidak boleh dijual oleh si ahli waris yang pada nantinya akan diteruskan lagi pada generasi selanjutnya.

Transeksual yang ingin menuntut dan mempertanyakan status hak warisnya di Adat Minangkabau, tentunya setelah penjelasan tersebut di atas tidak diperkenankan lagi untuk menerima waris. Transeksual tentunya dianggap sangat tabu dan mempermalukan baik bagi keluarga maupun kaum dan lingkungan adat. Sesuai pepatah "Dibuang Jauah di Gantuang Tinggi", yaitu dikeluarkan dari kaum bagi yang melanggar norma-norma dan mempermalukan suku serta kaum, tentunya disini Transeksual selain mempermalukan keluarga, kaum serta suku, ia juga telah melanggar dan melampaui batas-batas kesopanan, norma, agama dan menyalahi kodratnya sendiri.

\section{PENUTUP}

Keberadaan hukum waris di Indonesia masih pluralistik. Di Indonesia sistem hukum waris adat juga masih diakui, salah satunya ialah hukum waris adat matrilineal. Segala aturan Adat Minangkabau sepenuhnya bersandar pada ajaran Agama Islam. Lambat laun, seiring berkembangnya zaman dan globalisasi, muncul masalah-masalah yang dianggap melanggar norma dan kodrat sebagai manusia yaitu transeksual. Eksistensi Transeksual yang dahulunya dianggap tabu oleh masyarakat, lambat laun mulai muncul ke permukaan seiring berjalannya waktu. Di sisi lain, hal tersebut tidaklah bisa menggeser keberadaan nilai-nilai dan norma adat serta agama yang menjadi pedoman hidup masyarakat di Indonesia. Sejauh ini Transeksual di Indonesia tidak bisa diterima khususnya dalam lingkup dan pergaulan masyarakat adat. Keberadaan suatu hal yang dianggap menyimpang dari ajaran agama dan adat akan dijauhi dan diasingkan dari lingkungan masyarakat adat. Segala sesuatu mulai dari pergaulan, kegiatan, acara, hingga pewarisan sekalipun akan lepas dan tidak lagi melekat pada diri seorang Transeksual yang dianggap telah melanggar norma dan menyalahi kodratnya, khususnya dalam Adat Minangkabau yang menjunjung tinggi ajaran Agama Islam. Bahwa dalam segala aspek kehidupan termasuk pola tingkah laku masyarakatnya harus 
sesuai dengan ajaran Agama Islam, dimana dalam ajaran Agama Islam dikatakan masing-masing ciptaan-Nya itu membawa tugasnya sendiri-sendiri, mereka tidak boleh keluar dari ketentuan Allah. Semua aktivitasnya harus sesuai dengan fitrah yang telah dianugerahkan Allah kepadanya, serta Hadist yang menyatakan bahwa apa yang telah diciptakan oleh Allah tidak boleh dirubah. Maka dari itu, dapat dikatakan bahwa Transeksual tidak memiliki hak sebagai ahli waris dalam sistem pewarisan Adat Minangkabau, karena telah melanggar dan melampaui batas-batas kesopanan, norma, agama dan menyalahi kodratnya sendiri serta mempermalukan keluarga, kaum, dan sukunya.

Di sisi lain, status transeksual juga seringkali diajukan pengesahannya ke Pengadilan. Hal ini berarti status tersebut secara hukum telah sah, baik itu menjadi pria maupun wanita. Status baru yang telah ditetapkan oleh Pengadilan tersebut seharusnya diterima oleh masyarakat hukum adat karena secara hukum, status tersebut telah berubah. Namun, apabila masyarakat hukum adat tersebut tetap tidak dapat menerima penetapan Pengadilan mengenai penetapan status dari transeksual tersebut, maka harus dicapai harmoniasasi untuk menciptakan kesepakatan di antara seseorang dengan status barunya tersebut dengan kebiasaan masyarakat setempat.

\section{DAFTAR PUSTAKA}

\section{Buku}

Albar S. Subari. dkk. (2010). Pokok-Pokok Hukum Adat. Palembang: Penerbit Universitas Sriwijaya.

Amir M. S. (2002). Adat Minangkabau Pola dan Tujuan Hidup Orang Minang. Jakarta: PT. Mutiara Sumber Widya.

Garland. (2009). Hate Crime: Impact. Causes. and Respons. Londong: SAGE Publication

Hamka. (1968). Adat Minangkabau dan Harta Pusakanya. Padang: Center For Minangkabau Studies Press.

Judith Halberstam. (2005). In a Queer Time and Place: Transgender Bodies Subcutural Lines. NYU: Press.

Majelis Ulama Indonesia. (2010). Himpunan Fatwa Majelis Ulama Indonesia. Edisi Ketiga. Jakarta.

Soerojo Wignjodipoero. (1983). Pengantar dan Asas-Asas Hukum Adat. Jakarta: PT. Toko Gunung Agung. 
Sonny Dewi Judiasih,dkk. 2019. Susitainable Development Goals: Upaya Penghapusan Perkawinan Bawah Umur di Indonesia. Bandung: Cakra

\section{Jurnal}

Afdhal Prima. 2014.Sistem Pemerintahan Nagari (Studi Pada Nagari Padang Magek Kabupaten Tanah Datar). Volume 1 Nomor 2.

Anindita Ayu Pradipta Yudah. 2013. Representasi Transgender dan Transeksual dalam Pemberitaan di Media Massa: Sebuah Tinjauan Analisis Wacana Kritis. Jurnal Kriminologi Indonesia. Volume 9 Nomor 1.

Chatterjee Subhrajit. 2014. Problems Faced by LGBT People in Mainstream Society: Some Recommendation. International Journal of Interdisciplinary and Multidisciplinary Studies. Volume 1 Nomor 5.

Crews Douglas dan Crawford Marcus. 2015. Exploring the Role of Being Out on a queer

Person's Self Comparission. Journal of GayELesbian Social Serices. Volume 27 Nomor 2.

Roby Yansyah dan Rahayu. (2018). Globalisasi Lesbian. Gay. Biseksual. dan Trangender (LGBT): Perspektif HAM dan Agama dalam lingkup Hukum di Indonesia. Jurnal Law Reform. Volume 14 Nomor 1.

Sonny Dewi Judiasih. dkk. 2019. Sustainable Development Goals and Elimination of Children's Marriage Practice in Indonesia. Jurnal Notariil. Volume 4 Nomor 1.

Sri Warjiyati. 2018. Eksistensi Hukum Adat Dalam Penyelesaian Konflik pada Daerah Otonom. AHKAM. Jurnal Hukum Islam. Volume 6 Nomor 2.

Tia Powell. (2016). Transgender Rights as Human Rights. AMA Journal of Ethics. Volume 18 Nomor 11.

Ulfa Chaerani Nuriz. dkk. (2017). Penerapan Hukum Adat Minangkabau Dalam Pembagian Warisan Atas Tanah. Diponegoro Law Journal. Volume 6 Nomor 1.

Velly Fahazra Arza,dkk. (2017). Kewenangan Kerapatan Adat Nagari (KAN) Dalam Penyelesaian Sengketa Tanah Ulayat di Nagari Koto Baru Kabupaten Solok Berdasarkan PERDA Sumatera Barat 06 Tahun 2008. Volume 6 Nomor 2.

Yelia Nathassa Winstar. (2007). Pelaksanaan Dua Sistem Kewarisan Pada Masyarakat Adat Minangkabau. Jurnal Hukum dan Pembangunan. Volume 37 Nomor 2.

Yulianti Muthmainnah. (2016). LGBT Human Rights in Indonesian Policies. Indonesian Feminist Journal. Volume 4 Nomor 1. 


\section{Peraturan Perundang-Undangan}

Undang-Undang Dasar Tahun 1945.

Undang-Undang Nomor 23 Tahun 2006 Tentang Administrasi Kependudukan.

Undang-Undang Nomor 39 Tahun 1999 Tentang Hak Asasi Manusia.

\section{Sumber lain}

Wawancara Junaidi. Tokoh Adat: Datuak dalam Suku di Minangkabau.

Wawancara Marayulius, Tokoh Adat: Kerapatan Adat Nagari Minangkabau.

Wawancara Sutan Syahrul Nurmay. Ketua Kerapatan Adat Nagari 8 Suku Nagari Padang. 